\title{
METODE SPEOS (STIMULASI PIJAT ENDORPHIN, OKSITOSIN DAN SUGESTIF) DAPAT MENINGKATKAN PRODUKSI ASI DAN PENINGKATAN BERAT BADAN BAYI
}

\author{
Diah Eka Nugraheni ${ }^{1}$, Kosma Heryati ${ }^{2}$ \\ ${ }^{1,2}$ Jurusan Kebidanan, Politeknik Kesehatan Kementerian Kesehatan Bengkulu \\ Email: diah1234@gmail.com
}

\begin{abstract}
SPEOS (Stimulating Massage Endorphin, Oxytocin and Suggestive) Methods can Increase Breast Milk Production and Baby Weight. Target of achieving exclusive breastfeeding is $33.6 \%$, still low (IDHS 2010). Exclusive breastfeeding is intended to guarantee the fulfillment of the right of infants to 6 months old, with attention to growth and development, so that every mother would give exclusive breastfeeding to baby (PP no.23, 2012), the problem is that the milk does not come out in the first day of birth. It should be anticipated since pregnancies through lactation counseling, but the dissemination of information among the officers have not been optimized, so it was needed an alternative ways of stimulating milk production (Wiwin W, 2014). This study aims was to determine the SPEOS methods to increase milk production and baby weight.This research design used Quasi Experiment. Sample were primiparous postpartum mothers who were given the intervention SPEOS methods on the first day postpartum, were began 1-6 hours until the fourth week, then milk production measured before and after the intervention to see milk production and an increase in baby weight. The data analysed univariat analysis, Wilcoxon test bivariate analysis, multivariate analysis, and ANCOVA analysis to control confounding factors. This results showed the method SPEOS effect on milk production, average of $131.87(\mathrm{p}=0.00)$ and increased infant weight, average of $483.30 \mathrm{~g}(\mathrm{p} \mathrm{0.00)}$. Age and the food consumed by the mother during the study (maternal nutrition) did not affect milk production, whereas IMD effect on milk production with 0.389 square $r$ (p 0.04). SPEOS methods effect on milk production and an increase in baby weight on postpartum mother in Bengkulu City in BPM, 2016. Expected to all health workers can use the SPEOS method as a standard procedure in stimulate milk production to increase exclusive breastfeeding targets.
\end{abstract}

Keywords: SPEOS (Stimulating Massage Endorphin, Oxytocin and Suggestive) Methods, Infant Weight Milk Production

\begin{abstract}
Abstrak: Metode SPEOS (Pijat Endorphin, Oksitosin dan Sugestif) dapat Meningkatkan Produksi ASI dan Berat Badan Bayi. Target pencapaian ASI eksklusif masih Rendah yaitu 33,6\% (SDKI 2010). ASI eksklusif dimaksudkan untuk menjamin pemenuhan hak bayi untuk 6 bulan dengan memperhatikan pertumbuhan dan perkembangan, sehingga setiap ibu akan memberikan ASI eksklusif kepada bayi (PP no.23, 2012), masalah ASI tidak keluar di hari pertama kelahiran harus diantisipasi sejak kehamilan melalui konseling laktasi, tetapi penyebaran informasi di antara petugas belum dioptimalkan sehingga perlu dilakukan alternatif cara merangsang produksi susu (Wiwin W, 2014). Penelitian ini bertujuan untuk mengetahui metode SPEOS (Pijat endorphin, oksitosin dan sugestif) untuk meningkatkan produksi susu dan berat badan bayi. Desain penelitian ini digunakan Percobaan Quasi dengan sampel ibu nifas primipara diberi metode intervensi SPEOS pada hari postpartum pertama mulai 1-6 jam sampai minggu keempat, produksi ASI diukur sebelum dan setelah intervensi untuk melihat produksi susu dan peningkatan berat badan bayi. Data dianalisis univariat analisis dan analisis Wilcoxon uji bivariat dan analisis multivariat untuk mengontrol faktor pembaur dengan analisis ANCOVA. Hasil menunjukkan efek metode SPEOS rata-rata produksi susu dari 131,87 $(p=0,00)$ dan peningkatan bayi rata-rata berat $483,30 \mathrm{~g}(p 0,00)$, umur dan makanan yang dikonsumsi oleh ibu selama studi (gizi ibu) tidak mempengaruhi produksi susu, sedangkan efek IMD pada produksi susu dengan $0,389 \mathrm{r}$ persegi $(p$ 0,04). Kesimpulan: metode SPEOS berpengaruh pada produksi susu dan peningkatan berat badan bayi pada ibu nifas di Kota Bengkulu di BPM, 2016.Diharapkan semua petugas kesehatan yang memberikan bayi untuk dapat menggunakan metode sebagai prosedur standar dalam SPEOS merangsang produksi susu untuk meningkatkan target pemberian ASI eksklusif.
\end{abstract}

Kata kunci: Metode SPEOS (Stimulating Massage Endorphin, Oxytocin and Suggestive), Berat badan bayi, Produksi ASI 
WHO dan UNICEF merekomendasikan sebaiknya anak hanya diberi air susu ibu (ASI) selama paling sedikit 6 bulan dan pemberian ASI dilanjutkan sampai anak berumur dua tahun. ASI tidak terkontaminasi dan mengandung banyak zat gizi yang diperlukan oleh anak. pengenalan dini makanan rendah energi dan gizi atau yang dipersiapkan dalam kondisi tidak higienis dapat menyebabkan anak mengalami kurang gizi dan terinfeksi organisme asing sehingga mempunyai daya tahan tubuh yang rendah terhadap penyakit diatara anak-anak (Kemenkes RI,2014).

Di Asia Tenggara capaian ASI eksklusif menunjukan angka yang tidak banyak perbedaan. Sebagai perbandingan, cakupan ASI eksklusif di India sudah mencapai 46\%, di Philippines 34\%, di Vietnam 27\% dan di Myanmar 24\%. Secara Nasional laporan dinas kesehatan provinsi tahun 2013 cakupan ASI ekslusif pada bayi 0-6 bulan sebesar 54,3\% (Widayanti, Wiwin 2014), sedangkan secara global dilaporkan ASI ekslusif dibawah 40\%, angka ASI ekslusif di Indonesia lebih tinggi dibandingkan angka global (Kemenkes, 2014).

ASI ekslusif bertujuan untuk menjamin pemenuhan hak bayi untuk mendapatkan ASI ekslusif sejak lahir sampai berusia 6 bulan dengan memperhatikan pertumbuhan dan perkembangannya, sehingga setiap ibu yang melahirkan harus memberikan ASI ekslusif kepada bayi yang dilahirkannya (PP No.23 tahun 2012). Pengeluaran ASI merupakan suatu proses pelepasan hormon oksitosin untuk mengalirkan air susu yang diproduksi melalui saluran payudara.

Kegagalan dalam proses menyusui sering disebabkan karena timbulnya beberapa faktor, antara lain faktor ibu, faktor bayi, faktor psikologis, faktor tenaga kesehatan, faktor sosial budaya. Penelitian yang dilakukan oleh Diana (2007) menunjukan faktor penghambat pemberian ASI ekslusif berupa keyakinan yang keliru tentang makanan bayi, promosi susu formula, dan masalah kesehatan pada ibu dan bayi menyebabkan gagalnya pemberian ASI Eksklusif.

Adapun faktor ibu yang menjadi masalah dalam pemberian ASI adalah pengeluaran ASI, masalah pengeluaran ASI ini dipengaruhi oleh berkurangnya rangsangan hormon oksitosin, sedangkan perubahan pisik dan psikologis dapat mempengaruhi proses laktasi. Secara teori bahwa cara kerja hormon oksitosin dipengaruhi oleh kondisi psikologis, karena itu persiapan ibu pasca bersalin merupakan faktor penting yang dapat mempengaruhi keberhasilan menyusui, stress, rasa khawatir yang berlebihan, ketidak bahagiaan sangat berperan dalam kesuksesan menyusui.

Berbagai penelitian yang telah dilakukan di Indonesia untuk memperlancar produksi ASI diantaranya adalah metode Pijat Oksitosin, Teknik Marmet, Kompres Hangat, Massase Rolling (punggung), Breast Care, tetapi karena keterbatasan informasi di layanan kesehatan tentang prosedur pelaksanaan maka metodemetode ini hanya dikenal saja tetapi jarang diberikan oleh tenaga kesehatan sebagai care giver kepada pasien (Mas'ada, 2013).

Wiwin, W (2014) melakukan penelitian dengan metode SPEOS yaitu melakukan stimulasi untuk merangsang pengeluaran hormon oksitosin melalui pijat oksitosin, memberikan rasa nyaman dan menumbuhkan keyakinan pada ibu bahwa ASI pasti keluar dan ibu bisa memberikan ASI secara ekslusif dengan pijat endorphin dan sugestif, hasil penelitian bahwa metode speos merupakan alternatif cara untuk mengatasi masalah pengeluaran ASI pada harihari pertama kehidupan bayi.

Secara nasional cakupan ASI eksklusif di Indonesia masih rendah, data susenas 2010 menunjukkan baru 33,6\% bayi di Indonesia yang mendapatkan ASI eksklusif, hal ini berarti masih ada $2 / 3$ bayi di Indonesia yang kurang mendapatkan ASI (Emy Suryani, Kh Endah WidhiAstuti, 2013). Berdasarkan profil Kota Bengkulu (2014) dari sejumlah 4064 bayi yang lahir hanya 3306 bayi $(81,3 \%)$ yang mendapatkan ASI ekslusif. Berdasarkan hasil observasi peneliti ke BPM Kota Bengkulu belum adanya upaya untuk mengatasi masalah menyusui pada ibu nipas selain dengan obat-obatan dan susu formula.

Berdasarkan masalah dan kajian diatas maka peneliti tertarik untuk mengembangkan penelitian "Pengaruh metode speos (stimulasi pijat endorphin, pijat oksitosin dan sugestif) terhadap produksi ASI dan peningkatan berat badan bayi" dengan mengontrol variabel usia,IMD dan makanan yang dikomsumsi ibu selama nipas (nutrisi) pada Ibu nifas di BPM Kota Bengkulu tahun 2016".

\section{METODE PENELITIAN}

Desain penelitian adalah kuasi eksperimen dengan rancangan pre and post test desain pengukuran dilakukan sebelum dan setelah melakukan intervensi metode SPEOS yaitu melakukan kombinasi pijat endorphin, pijat oksitosin dan sugesti dimulai 1-6 jam post partum setiap hari sampai dengan minggu ke 4 . 
Populasi dalam peneliatian ini adalah seluruh ibu nifas di BPM Kota Bengkulu tahun 2016 dengan sampel ibu nifas primipara yang melahirkan sebanyak 30 orang sampel diambil secara consecutive sampling dengan kriteria inklusi primipara, Nifas hari 1 (1-6 jam post partum), bayi tidak diberikan susu formula, BB $\geq 2500$ gram, kriteria ekslusi ibu yang menolak menjadi responden, merokok, kondisi ibu dan bayi tidak sehat (komplikasi/ kasus kegawatdaruratan).

Pengumpulan data dilakukan secara langsung dimulai melakukan pelatihan enumerator, menentukan responden sesuai dengan kriteria inklusi dan ekslusi, kontrak penelitian dengan responden, petugas (enumerator) yang melakukan penelitian 1 orang untuk 1 ibu nifas sampai selesai, intervensi dilakukan oleh peneliti dan enumerator yang sudah dilatih dengan menggunakan protap metode SPEOS. Pijat dilakukan setiap hari dimulai hari ke 1 (1-6 jam post partum) s/d 4 minggu, lama pijat dimulai dengan 10 menit minggu I, kemudian dinaikkan 15 menit minggu ke II, lalu dievaluasi bila produksi ASI sedikit maka waktu pijat dinaikkan sampai 20 menit dan dipertahankan sampai minggu ke IV, penilaian produksi ASI dilakukan dengan cara memompa ASI, dengan menggunakan pompa Pigeon (ml), ASI dipompa sebelum dan sesudah pemijatan setiap minggu sampai dengan minggu ke 4, dipompa 2 jam sebelum bayi menyusui, penimbangan berat badan bayi dilakukan setiap minggu bersamaan melakukan pemompahan ASI. Pengolahan dan analisa data menggunakan uji sampel non parametric wilcoxon test, sedangkan untuk mengontrol factor perancu dilakukan analisa $t$ test dependen dan dilanjutkan dengan uji multivariat analisis ancova.

\section{HASIL}

Tabel 1. Analisis Diskripsi Berdasarkan Usia, IMD dan Penambahan Susu Ibu Menyusui pada Ibu Nifas dengan Pijat SPEOS

\begin{tabular}{lrrrr}
\hline \multicolumn{1}{c}{ Karakteristik } & F & $\mathbf{( \% )}$ & Mean & SD \\
\cline { 1 - 3 } Usia & & & & \\
20-30 Tahun & 29 & 96 & & \\
>30 tahun & 1 & 4 & & \\
\cline { 1 - 2 } IMD & & & & \\
Ya & 24 & 80 & 25.63 & 3,37 \\
Tidak & 6 & 20 & & \\
\cline { 1 - 3 } Nutrisi & 18 & 60 & & \\
Ya & 12 & 40 & & \\
Tidak & 30 & 100 & \\
\hline \multicolumn{1}{r}{ Total } & & &
\end{tabular}

Berdasarkan analisis tabel 1 rata-rata usia ibu nifas adalah 25,63 tahun, sebagian besar persalinan dengan IMD dan hampir sebahagian ibu mengkomsumsi nutrisi berupa biscuit dan susu ibu menyusui.

Tabel 2. Rerata Produksi ASI, Peningkatan Berat Badan Bayi dan Lama Menyusui Sebelum dan Sesudah Dilakukan Metode SPEOS pada Ibu Nifas

\begin{tabular}{|c|c|c|c|c|c|c|}
\hline Variabel & Vaktu & $\mathbf{n}$ & Mean & Sd & Min & Maks \\
\hline Produksi & Mg I & 30 & & & & \\
\hline \multirow[t]{11}{*}{ ASI (ml) } & Pre & & 3,30 & 3,94 & 0 & 10 \\
\hline & Post & & 99,50 & 14,28 & 65 & 140 \\
\hline & Mg II & 30 & & & & \\
\hline & Pre & & 96,00 & 19,75 & 25 & 140 \\
\hline & Post & & 114,50 & 15,27 & 90 & 150 \\
\hline & Mg III & 30 & & & & \\
\hline & Pre & & 108,50 & 13,71 & 80 & 130 \\
\hline & Post & & 125,33 & 11,74 & 100 & 140 \\
\hline & Mg IV & 30 & & & & \\
\hline & Pre & & 117,83 & 13,81 & 95 & 150 \\
\hline & Post & & 135,17 & 10,54 & 120 & 150 \\
\hline \multirow{12}{*}{$\begin{array}{l}\text { Berat } \\
\text { Badan } \\
\text { Bayi (gr) }\end{array}$} & $\mathrm{Mg} \mathrm{I}$ & 30 & & & & \\
\hline & Pre & & 2975 & 420,33 & 2200 & 4000 \\
\hline & Post & & 2855 & 416,54 & 2100 & 3850 \\
\hline & Mg II & 30 & & & & \\
\hline & Pre & & 2855 & 416,54 & 2100 & 3850 \\
\hline & Post & & 3021,67 & 402,58 & 2400 & 4000 \\
\hline & Mg III & 30 & & & & \\
\hline & Pre & & 3021,67 & 402,58 & 2400 & 4000 \\
\hline & Post & & 3203,33 & 435,28 & 2300 & 4300 \\
\hline & Mg IV & 30 & & & & \\
\hline & Pre & & 3203,33 & 435,28 & 2300 & 4300 \\
\hline & Post & & 3458,33 & 444,13 & 2600 & 4600 \\
\hline \multirow{4}{*}{$\begin{array}{l}\text { Lama } \\
\text { Menyu- } \\
\text { sui }\end{array}$} & Mg I & 30 & 30,33 & 1,82 & 30 & 40 \\
\hline & Mg II & 30 & 26,00 & 5,15 & 20 & 35 \\
\hline & Mg III & 30 & 30,33 & 5,86 & 20 & 50 \\
\hline & Mg IV & 30 & 30,33 & 3,19 & 25 & 40 \\
\hline
\end{tabular}

Berdasarkan analisis tabel 2 peningkatan produksi ASI sebelum dan setelah dilakukan intervensi pada minggu ke 1, 2, 3 dan ke 4 . Peningkatan produksi ASI banyak terjadi pada minggu I (140 ml), Terjadi penurunan BB bayi rata-rata minggu I sebanyak 120 gr, kemudian terjadi peningkatan pada $\mathrm{mg}$ II s/d ke IV sebanyak 255 gr. Rata-rata lama ibu menyusui setiap minggu adalah 26-30,33 menit. 
Tabel 3. Analisis Pengaruh Metode SPEOS terhadap Peningkatan Produksi ASI dalam Minggu pada Ibu Nifas

\begin{tabular}{llrrrrr}
\hline \multicolumn{1}{c}{ Variabel } & Metode & \multicolumn{2}{c}{$\sum$ Produksi ASI (mI) } & \multirow{2}{*}{$\begin{array}{c}\text { Peningkatan } \\
(\mathbf{m l})\end{array}$} & $\boldsymbol{p}$ \\
\cline { 3 - 4 } & Speos & \multicolumn{1}{c}{ Sebelum } & \multicolumn{1}{c}{ Sesudah } & & \\
\hline$\sum$ Produksi & Mg I & 30,33 & 99,50 & 96,17 & 0,001 \\
ASI (ml) & Mg II & 96,00 & 114,50 & 18,50 & 0,001 \\
& Mg III & 108,50 & 125,33 & 16,53 & 0,001 \\
& Mg IV & 117,83 & 135,17 & 17,37 & 0,001 \\
\hline$\sum$ BB Bayi & Mg I & 2975 & 2855 & -120 & 0,001 \\
(gram) & Mg II & 2855 & 3021,67 & 166,67 & 0,001 \\
& Mg III & 3021,67 & 3203,33 & 182 & 0,001 \\
& Mg IV & 3203,33 & 3458,33 & 255 & 0,001 \\
\hline$\sum$ Lama & Mg I & 30,33 & 99,50 & & 0,001 \\
Menyusui & Mg II & 26,00 & 114,50 & & 0,001 \\
& Mg III & 30,33 & 125,33 & & 0,001 \\
& Mg IV & 30,33 & 135,17 & & 0,001 \\
\hline
\end{tabular}

Berdasarkan analisi tabel 3 peningkatan produksi ASI metode SPEOS dari minggu I s/d minggu ke 4 , dengan $p$ 0,00. Peningkatan produksi ASI terbanyak pada minggu I $(96,17$ ml) $p 0,00$, selanjutnya diikuti pada minggu ke 2 sebanyak $18,50 \mathrm{ml}$ dengan $p 0,00$, minggu ke 3 dan ke 4 peningkatan produksi ASI hampir sama. Terjadi penurunan berat badan bayi pada minggu I kelahiran sebanyak 120 gram, minggu ke 2,3 dan 4 antara 166- 255 gram dengan $p 0,00$, ratarata lama menyusui antara 26-30,33 menit dapat meningkatkan produksi ASI antara 99,50-135,17 ml, dengan $p 0,00$ pada ibu nifas di BPM Kota Bengkulu Tahun 2016

Tabel 4. Analisis Pengaruh Metode SPEOS terhadap Peningkatan Produksi ASI pada Ibu Nifas

\begin{tabular}{lcccc}
\hline Variabel & Sebelum & Sesudah & $\begin{array}{c}\sum \text { Peningkatan } \\
(\mathbf{m l})\end{array}$ & $\boldsymbol{p}$ \\
\hline$\sum_{\text {Produksi }}$ & 3,30 & 135,17 & 131,87 & 0,001 \\
ASI (ml) & & & & \\
\hline $\begin{array}{l}\sum_{\text {BB }} \text { bayi (gr) } \\
\text { nay }\end{array}$ & 2975 & 3458,33 & 483,30 & 0,001 \\
\hline
\end{tabular}

Berdasarkan analisi tabel 4 di atas dapat disimpulkan bahwa metode SPEOS berpengaruh terhadap produksi ASI sebanyak 131,87 ml dengan $p$ 0,001dan peningkatan berat badab janin sebanyak 483,30 gr dengan $p 0,001$

Tabel 5. Analisis Faktor Usia, IMD dan Nutrisi pada Ibu Nifas terhadap Produksi ASI

\begin{tabular}{lrrr}
\hline Variabel & \multicolumn{2}{c}{ 95 \% CI } & $\boldsymbol{p}$ \\
\cline { 2 - 3 } & Lower & Upper & \\
\hline Usia & $-103,720$ & $-93,080$ & 0,000 \\
IMD & $-104,565$ & $-94,035$ & 0,000 \\
Nutrisi & $-104,445$ & $-93,755$ & 0,000 \\
\hline
\end{tabular}

Berdasarkan analisis tabel 5 di atas dapat disimpulkan bahwa variabel usia, IMD dan
Nutrisi berpengaruh terhadap produksi ASI, sehingga variabel ini akan dimasukkan ke dalam analisis multivariat $(p>0,025)$.

Tabel 6. Analisis Pengaruh Usia, IMD dan Nutrisi terhadap Produksi ASI pada Ibu Nifas

\begin{tabular}{lrc}
\hline \multicolumn{1}{c}{ Variabel } & P value & R Square \\
\hline Usia & 0,43 & 0,389 \\
IMD & 0,04 & \\
Nutrisi & 0,33 & \\
\hline
\end{tabular}

Ket: Anova

Berdasarkan analisis tabel 6 bahwa usia ( $p$ $0,43)$ dan nutrisi $(0,33)$ tidak berpengaruh terhadap produksi ASI, sedangkan IMD berpengaruh terhadap produksi ASI dengan nilai $p$ 0,04 dan $\mathrm{R}$ Square 0,389 artinya IMD memberikan pengaruh terhadap produksi ASI sebanyak 0,04, dengan peluang sebesar $38 \%$ $(<60 \%)$.

\section{PEMBAHASAN}

Berdasarkan hasil penelitian, Metode SPEOS berpengaruh terhadap produksi ASI, ratarata peningkatan produksi ASI sebesar 135,17 ml dengan $p$ 0,00. Metode SPEOS (Stimulasi Pijat Endorphin, Oksitosin dan Sugestif) ini dilakukan dengan mengkombinasikan antara pijat endorphin, pijat oksitosin dan sugestif/ afirmasi positif yang bertujuan membantu ibu nifas (menyusui) memperlancar pengeluaran produksi ASI dengan cara menstimulasi untuk merangsang pengeluaran hormon oksitosin, seorang ibu menyusui tidak dibantu dari aspek pisik tetapi ibu menyusui dibantu untuk dapat beradaptasi secara psikologis, dimana hormon oksitosin sensitif dengan kondisi psikologis ibu, dengan demikian 
ibu dapat melanjutkan kelangsungan ASI ekslusif (Widayanti, 2014).

Penelitian ini dilakukan pada ibu nipas primi para dengan usia rata-rata 25,63 tahun yaitu usia minimum 20 tahun dan usia maksimun 32 tahun. Menurut pendapat Biancuzo (2003) usia yang terbaik untuk melahirkan adalah usia 20 sampai dengan 35 tahun, karena usia ini merupakan salah satu faktor yang mempengaruhi produksi ASI. Ibu-ibu yang usianya kurang dari 35 tahun lebih banyak memproduksi ASI dibandingkan dengan ibu-ibu yang usianya lebih tua, tetapi ibu-ibu yang sangat muda (kurang dari 20 tahun) produksi ASInya juga kurang banyak karena dilihat dari tingkat kematurannya, namun dalam penelitian ini dialakukan analisa confounding usia bukanlah faktor yang mempengaruhi produksi ASI.

Hasil penelitian menunjukkan rata-rata peningkatkan produksi ASI pada minggu 1 ratarata sebanyak $96,17 \mathrm{ml}$ dengan $p 0,05$, sedangkan minggu ke 2, 3 dan ke 4 hampir sama. Hal ini menunjukkan adanya kesesuaian dengan teori bahwa dengan melakukan kombinasi pijat endorphin, oksitosin dan melakukan sugestif dengan melakukan pijatan sepanjang tulang belakang (vetebrae) sampai tulang costae kelimakeenam, dan membawa ibu untuk dapat melakukan relaksasi, akan merangsang otak dapat mengeluarkan hormon endorphin, hormon prolaktin dan oksitosin, sehingga ASI menjadi lancar, memberikan kenyamanan pada ibu nifas dan menghilangkan sumbatan sehingga hambatan dalam menyusi minggu pertama dapat teratasi dengan baik. Apabila pada minggu pertama produksi ASI sudah berjalan dengan lancar maka produksi ASI selanjutnya akan menjadi lebih lancar dan ibu dapat melanjutkan proses menyusui dengan baik sehingga tercapailah program ASI ekslusif (Astutik, Sri, 2007).

Hasil penelitian menunjukkan produksi ASI ibu nifas setelah diberikan intervensi metode SPEOS semua ibu berhasil menyusui karena produksi ASI nya yang cukup serta ibu dapat melanjutkan pemberian ASI ekslusif ( $p=$ $0,05)$ artinya ada pengaruh metode SPEOS terhadap produksi ASI dan peningkatan berat badan bayi.

Hasil penelitian ini sesuai dengan hasil penelitian yang dilakukan oleh (Wijayanti,2014), semakin lancar produksi ASI semakin banyak pula produksi ASI dan semakin banyak produksi ASI maka peningkatan berat badan bayi semakin baik, dengan melakukan pemijatan ibu merasa rileks, lebih nyaman, kelelahan setelah melahirkan hilang dan ibu merasa yakin akan dapat memerikan ASI secara ekslusif selama 6 bulan. Apabila ibu primi sudah berhasil memberikan ASI kepada bayi, maka pada persalinan berikutnya ibu yakin dapat membeikan ASI (Mardiyah N, 2010).

Hasil penelitian ini menunjukkan bahwa metode SPEOS berpengaruh terhadap peningkatan Berat badan bayi pada ibu nifas di BPM Kota Bengkulu Tahun 2016 rata-rata sebanyak 483,33 gram dengan $p 0,00$. Menurut Nugroho (2011), gizi ibu menyusui sangat erat kaitannya dengan produksi ASI yang sangat dibutuhkan untuk tumbuh kembang bayi. Apabila produksi ASI lancar, maka proses menyusi akan berjalan dengan baik. Bila pemberian ASI berhasil maka berat badan bayi akan meningkat.

Hasil penelitian pada minggu I terjadi penurunan berat badan bayi rata-rata sebanyak 120 gr, hal ini sesuai dengan teori bahwa pada minggu I kelahiran terjadi penurunan berat badan bayi sebanyak $7-10 \%$ dan terjadi peningkatan berat badan bayi sampai minggu ke VI minimal 500 gr, hal ini adalah normal (Fatimah B, dkk, 2014). Kehilangan berat badan pada minggu I kelahiran ini disebabkan oleh kehilangan cairan dan pemenuhan kebutuhan ASI yang belum tercukupi, kemudian pada minggu ke II berat badan bayi akan meningkat kembali sesuai dengan berat badan lahir, selanjutnya pada akhir minggu ke VI terjadi peningkatan berat badan sebanyak minimal 500 gr.

Hasil penelitian ini menunjukkan bahwa metode SPEOS dapat meningkatkan berat badan bayi pada semua bayi minggu ke II rata-rata sebanyak 166,67 gr, yang seharusnya pada minggu ke II berat adan bayi akan sama dengan berat badan lahir, sehingga dapat disimpulkan bahwa metode SPEOS dapat meningkatkan dan memperlancar produksi ASI sehingga memberikan dampak terhadap kenaikkan berat badan bayi. Hasil penelitian ini sesuai dengan hasil penelitian yang dilakukan oleh (Widayanti, 2014), bahwa semakin lancar produksi ASI semakin banyak pula produksi ASI dan semakin banyak produksi ASI maka peningkatan berat badan bayi semakin baik.

Lama menyusui berpengaruh terhadap produksi ASI, lama menyusui menggambarkan bahwa ASI dihisap oleh bayi sampai payudara kosong, sehingga apaila payudara kosong maka ASI akan diganti dengan ASI yang baru, tetapi apabila bayi tidak mengosongkan ASI sampai payudara kosong maka sisa ASI harus dikeluarkan melalui pompa dan ASI dapat disimpan untuk persiapan ASI apabila ibu pergi berkerja diluar rumah. Menurut Soetjiningsih (2007) menyatakan bahwa sebaiknya menyusui bayi tanpa dijadwal karena bayi akan 
menentukan sendiri kebutuhannya. Pada awalnya bayi akan menyusui dengan jadwal yang tidak teratur, dan akan mempunyai pola tertentu setelah 1-2 minggu kemudian. Bayi yang sehat dapat mengosongkan payudara sekitar 5-7 menit dan ASI dalam lambung bayi akan kosong dalam waktu 2 jam.

Hasil analisis multivariat yaitu untuk mengontrol variabel perancu yang dapat mempengaruhi produksi ASI dalam penelitian ini usia, IMD dan nutrisi ibu dengan hasil bahwa usia dan nutrisi ibu bukan merupakan faktor yang berpengaruh terhadap produksi ASI, sedangkan IMD berpengaruh terhadap produksi ASI sebanyak 0,375 artinya IMD memberikan peluang mempengaruhi produksi ASI $37,5 \%$ sedangkan sisanya dipengaruhi oleh faktor lain seperti faktor kelelahan, psikologis (ketenangan jiwa dan lain-lain) yang tidak diteliti dalam penelitian ini.

Menurut Roesli (2009), bahwa IMD (Inisiasi Menyusui Dini) adalah suatu tindakan yang dilakukan dengan meletakkan bayi sesgera setelah lahir dengan tujuan adalah bayi dapat mencari puting susu, rangsangan puting ini akan merangsang pengeluaran hormon oksitosin yang berfungsi untuk kontraksi uterus untuk perlepasan dan merupakan langkah awal rangsangan puting untuk mengeluarkan kolostrum yang dapat memperlancar produksi ASI pada hari-hari pertama kelahiran bayi, IMD adalah faktor pemukim yang kuat terhadap keberhasilan menyusui (Fikawati \& Syafiq, 2010).

\section{SIMPULAN}

1. Rata-rata produksi ASI pada ibu nifas yang dilakukan metode SPEOS minggu I (96,50ml), minggu ke II $(18,50 \mathrm{ml})$, minggu Ke III (16,53ml) dan minggu ke IV $(17,37 \mathrm{ml})$.

2. Rata-rata peningkatan berat badan bayi Minggu I (-120gr), minggu ke II $(166,67 \mathrm{gr})$, minggu ke III (182gr), minggu ke IV (255gr).

3. Ada berpengaruh Metode SPEOS terhadap produksi ASI, rata-rata sebanyak $131,87 \mathrm{ml}$ dengan $p 0,05$.

4. Ada pengaruh metode SPEOS terhadap produksi terhadap peningkatan berat badan bayi pada ibu nifas, rata-rata sebanyak 483,30 gr dengan $p 0,05$

5. Usia dan nutrisi bukan faktor yang berpengaruh terhadap produksi ASI, sedangkan IMD berpengaruh terhadap produksi ASI sebesar $38 \%$ sisanya adalah faktor lain.

\section{SARAN}

1. Ibu nifas dapat melaksanakan metode SPEOS mulai 6 jam nifas s/d minggu I kelahiran untuk merangsang produksi ASI terutama ibu primi agar program ASI ekslusif dapat tercapai, pemenuhan kebutuhan ASI bayi cukup dan berat badan bayi cepat meningkat.

2. Menjadikan metode SPEOS sebagai protap perawatan yang dilakukan mulai 6 jam pertama kelahiran sampai dengan I minggu nifas, sehingga target ASI ekslusif dapat tercapai (Bayi sehat, tumbang berjalan dengan sempurna dan generasi penerus yang cerdas).

3. Memasukkan intervensi metode SPEOS kedalam paket pembayaran persalinan pada BPJS sebagai tambahan insentif bidan

4. Peneliti selanjutnya dapat melanjutkan penelitian ini untuk melihat berapa peningkatan kadar hormon oksitosin pada saat dilakukan metode SPEOS.

\section{DAFTAR PUSTAKA}

A Bari Syaifuddin. 2000. Pelayanan Maternal dan Neonatal. Jakarta: EGC.

Aprilia Yesie. 2010. Hipnostetri. Rileks Nyaman dan Aman saat Hamil dan Melahirkan. Jakarta: Gagas Media.

Biancuzzo, M. 2003.Breastfeeding The Newborn: Clinical Strategies for Nurses. St.Louis: Mosby.

Bobak, LM, Lowdermilk, DL, \& Jensen, M.D. 2005. Buku Ajar Keperawatan Maternitas (Maria A. Wijayanti \& Peter Anugrah, penerjemah). Jakarta: EGC.
Cunningham, F.G, Mc Donald, P.C.Grant, N.F. 1995. Obstetri Williams (Suyono \& Hartono, Penerjemah). Jakarta: EGC.

Depkes RI. 2001. Panduan Managemen Laktasi.

Desmawati. 2008. Efektifitas Kombinasi Areola Massage dan Rolling Massage terhadap Pengeluaran ASI Secara Dini pada Ibu Nifas di Puskesmas Pamulang dan Cikupa Banten. Tesis. Depok. FIK. UI

Emy Suryani, Kh Endah Widhi Astuti. 2013.Pengaruh Pijat Oksitosin terhadap Produksi ASI Ibu Postpartum di BPM Wilayah Kabupaten Klaten. Politeknik 
Kesehatan Surakarta.

Fatimah. 2007. Karakteristik Dan Faktor Ibu dalam Pemberian ASI Eksklusif Pada Bayi Usia 0-6 bulan di Kelurahan Suka Ramai I Kecamatan Medan Area Kota, Tahun 2007. FKM USU. Medan.

Fikawati S, Syafiq A. 2010. Kajian implementasi dan kebijakan air susu ibu eksklusif dan inisiasi menyusu dini di Indonesia. Jurnal Makara; Seri Kesehatan.

Ibrahim. 2000.Hubungan Sikap Ibu dengan Pemberian ASI Eksklusif di Wilayah Kerja Puskesmas Cot Weh pada Bayi (0-11 Bulan) di Kabupaten Aceh Besar Propinsi Daerah Istimewa Aceh. Tesis. FKM USU. Medan.

Kemenkes RI. 2014. Situasi dan Analisis ASI Ekslusif. Jakarta.

Manuaba, I. B. G. 2012. Ilmu Kebidanan, Ilmu Kandungan, dan Keluarga Berencana. Jakarta: Penerbit Buku Kedokteran EGC.

Mardiningsih, Eko. 2010. Efektifitas Kombinasi Teknik Marmet dan Pijat oxytocin terhadap Produksi ASI Ibu Post Section Caesaria di Wilayah Rumah Sakit wilayah Jawa Tengah. Tesis. Jakarta: Universitas Indonesia.

Marlina, W. Novitasari, D. \& Trisnasari, A. 2013. Pengaruh Teknik Marmet terhadap Produksi ASI pada Ibu Post Sectio Caesarea di RSUD Ambarawa tahun 2013. Kepustakaan Ungaran 23.
Mas'adah. 2013. Tehnik Meningkatkan dan Memperlancar Produksi ASI pada Ibu Post Section Caesaria. Poltekkes Kemenkes Mataram.

Notoatmojo, S. 2005. Metode Penelitian Kesehatan. Jakarta: Rineka Cipta.

Perinasia. 2011. Program Manajemen Laktasi. Jakarta: Bina Rupa Aksara.

Prawiro. 2007.Ilmu Kebidanan. Jakarta: Balai Pustaka.

Pemerintah Kota Bengkulu. 2015. Profil Kota Bengkulu Tahun 2014.

Perinasia. 2004. Bahan Bacaan Manajemen Laktasi: Menuju Persalinan Aman dan Bayi Lahir Sehat. Jakarta: Perinasia.

Purwanti. 2004. Konsep Penerapan ASI Eksklusif. Bandung: Cendekia.

Roesli, U. 2009. Mengenal ASI Eksklusif. Jakarta: PT. Pustaka Pembangunan Swadaya Nusantara.

Sastroasmoro, S. 2002. Dasar-dasar Metodologi Penelitian Klinis. Jakarta: Sagung Seto.

Siregar, A. 2004. Pemberian ASI Eksklusif dan Faktor-faktor yang Mempengaruhinya. Medan: FKM USU.

Soetjiningsih. 2007. ASI Petunjuk Untuk Tenaga Kesehatan. Jakarta: EGC.

Widayanti Wiwin. 2014. Efektivitas Metode "Speos" (Stimulasi Pijat Endorphin, Oksitosin dan Sugestif) terhadap Pengeluaran ASI pada Ibu Nifas. UNDIP. 